\title{
Harvesting methods of Cinnamomum tamala leaves in private land: a case study from Udayapur district, Nepal
}

\author{
D. Lamichhane ${ }^{1}$ and N.K. Karna ${ }^{2}$
}

\begin{abstract}
Tejpat (Cinnamomum tamala) leaf is commercially one of the important non-timber forest products of Nepal. This paper attempts to elaborate and analyze the harvesting methods and techniques of Tejpat grown by the farmers in their private land. The study was conducted in the villages of Udayapur district where Tejpat was widely cultivated and harvested for income generation and trading purposes. Almost all farmers with private land had planted Tejpat. Complete lopping of leaves once a year was the exclusive practice for harvesting. The collection period for leaf was from Ashoj (October) to Magh (February) but the period for bark varied greatly, i.e. from Kartik to Poush (November to January) and Baisakh / Jestha (May / June). Bark collection was done only from old, dying, diseased and low leaf producing trees. Average number of trees per household ranged from 10 to 155 . The mean diameter at breast height (DBH) of the trees was 39.58 $\mathrm{cm}$. There was high positive correlation between the DBH and fresh weight of leaf. Fitting of linear regression of fresh weight of leaf with DBH proved that the relationship was statistically significant at $5 \%$ level of significance. The minimum age and size of trees for leaf harvesting were found to be five years and $16.18 \mathrm{~cm}$, respectively.
\end{abstract}

Keywords: Fresh weight, harvesting, private land, Tejpat

T ejpat (Cinnamomum tamala, Buch.-Ham.) belongs to Lauraceae family and is widely distributed throughout South Asian countries. The tree is commercially known as Indian cassia. It grows wild in Nepal in between $450-2100 \mathrm{~m}$ elevation. It is commercially cultivated especially in Udaypur and Palpa districts (Bhattarai, 2001). It has been used in traditional medicines as an astringent, stimulant and carminative. The leaves of $C$. tamala have been used in Nepal for flavouring food and as medicinal ingredient. The leaves are used as a spice but can be employed with myrobalans during dyeing and in the manufacture of vinegar. It is also used as fodder. The essential oil from the leaves is also used as a flavouring agent. The components of Tejpat leaf oil were constituted of linalool $(54.66 \%)$, a-pinene (9.67\%), p-cymene $(6.43 \%)$, B-pinene $(4.45 \%)$, limonene $(2.64 \%)$ and sixteen minor components less than 2\% (Upadhaya et al., 1994). The leaf oil is a rich source of eugenol (Krishnamurthy, 1996). The bark has been used as a substitute for true cinnamon, Cinnamomum zelanicum Breyn, which does not grow in Nepal (Jackson, 1994). Tejpat leaf and bark fall under low value products in Nepal, unlike Jatamansi, Chirayito, etc. (Amatya and Shrestha, 2003). Both wild and domesticated cinnamomum species fulfill subsistence requirements of many people especially for members of minority ethnic groups living in economically disadvantaged and physically remote locations of Nepal (Parajuli, 1997).

Tejpat is generally harvested in dry and mild weather from October to December and in some places, the collection is continued till the month of March (Upadhaya et al., 1994). Tejpat leaves are 10-15 cm long, opposite with three veins running from the base to the apex and lanceolate with short blunt points. The leaves are collected once a year from young trees, and every other year from old and weak ones (Krishnamurthy, 1996). In harvesting the Tejpat leaf, the small branches are excised with the leaves and dried in the shade for 3-4 days. The leafy branches are then bundled for the market. On an average, 13 $\mathrm{kg}$ of dry leaves may be obtained from a tree but the quantity depends upon the local factors; a tree can yield from 8-20 $\mathrm{kg}$ of dry leaves in a year (TISC, 2003). According to Bhattarai (2001) a tree produces 10-25 $\mathrm{kg}$ of dry leaves and its $0.2-0.4 \%$ oil can be extracted from leaves. Timely collection of leaf is important since early and late collection may result in poor quality of the leaves or essential oil. Generally, leaves should be harvested before flowering. High rainfall

\footnotetext{
Assistant Research Officer, Department of Forest Research and Survey, Kathmandu, Nepal.

Email: dhananjayalamichhane@yahoo.com

2 Assistant Research Officer, Department of Forest Research and Survey, Kathmandu, Nepal.
} 
reduces the aroma of leaves. Since the cultivation cost is modest, this is a profitable crop (Bhattarai, 2001). The price paid to the collectors has no relation to the wholesale price at the terminal market (Khatri, 1994). Edwards (1996) has documented Tejpat as an important non-timber forest product Nepal trades with India.

Although some studies have been carried out on Tejpat inventory and leaf/bark biomass for some districts, studies on scientific harvesting methods are lacking and systematic researches on this species have not been done. The purpose of the study was to explore and analyze the harvesting techniques of Tejpat leaf; and to relate the green weight of Tejpat leaf with different ages.

\section{Materials and methods}

The study was conducted on private forest lands and farmland plantation areas of Udayapur district in eastern Nepal. The forests in this district ranges from Terai to Mahabharat range. The forest types include tropical evergreen forest to Alder forest. More than $80 \%$ area is in high temperature zone. The rest of the areas has temperate climate. Most of this region are extremely sloped in the northern part of Churiya. Some of the district lies on plain lands. The study was confined to Betani, Huwas, Ranibas, Jyamirpakho, Jyamitar and Damling villages of Khabu VDC Ward No. 1, 2 and 8 of Udayapur district. The total number of respondents (both male and female) was 200, and the main ethnic groups represented of the study area were Magar, Rai, and Brahmin.

The existing traditional and advanced techniques of harvesting methods were identified by social survey. A set of questionnaires was used for interviews with farmers who had grown Tejpat trees on their private land and had been harvesting bark and leaf. After identifying the different harvesting techniques used by the farmers, a total of 42 trees with different ages were selected for the assessment of the existing harvesting methods by cutting and weighing of the leaves. Field work encompassed social survey, trees selection, diameter at breast height $(\mathrm{DBH})$ and height measurement, harvesting of leaf and weight measurements. The records of all activities were documented carefully and precisely. The main variables measured were: number of trees per household $(\mathrm{HH}), \mathrm{DBH}$, fresh weight of leaf, and height of the trees. The height of the trees was estimated sunto-clinometer. Different groups of stakeholders such as primary producers/collectors, district cooperatives, community forest user groups, and the District Forest Office were consulted. Informal discussions with selected collectors at local markets, group discussion with Tejpat growing farmers, discussion with traders at the road head of Gaighat were done. The District Forest Office staff including concerned field Ranger and farmers were consulted for information relating to Tejpat cultivation and harvesting. They were mainly asked questions relating to their experience and traditional knowledge on leaf harvesting methods for high productivity and sustainability of the trees.

\section{Results and discussion}

\section{Cultivation of Tejpat}

Agriculture was the exclusive livelihood of the majority of the people in the area, although a few were involved in agriculture and shop keeping, and agriculture and labor. The family size ranged from 5 to 12 with an average of 8 . Almost all farmers were found to have owned private land and cultivated Tejpat trees. The average number of trees per household was 72, ranging from minimum 10 to maximum 155 trees (Table 1). Most of the trees were of the age between 5-25 years. Regarding DBH and frequency of the trees, the DBH range of harvestable trees was $16.18 \mathrm{~cm}$ to $53.59 \mathrm{~cm}$ and their corresponding height was $5 \mathrm{~m}$ to $12 \mathrm{~m}$, respectively. They were grown mainly on marginal lands, risers, and farmlands. Tejpat regeneration was from the seedlings collected from natural forest and then from self germination by seed dispersal from mother trees, but only a very few (about 10\%) originated from nursery seedlings. The trees generally had not been planted but sprouted from the mother trees in the

Table 1 : An overview of Tejpat cultivation

\begin{tabular}{lrrrr}
\hline Variable/particular & Mean & Std. Dev. & Minimum & Maximum \\
\hline Family size & 8 & - & 5 & 12 \\
Trees/HH & 72 & - & 10 & 155 \\
Annual Income/ Tree/HH (NRs.) & 1200 & - & 200 & 2500 \\
DBH (cm) & 39.58 & 10.08 & 16.18 & 53.39 \\
Height (m) & 8.17 & 1.72 & 5 & 12 \\
Fresh weight of leaf (kg) & 110.35 & 57.41 & 16 & 205 \\
\hline
\end{tabular}


locality. Very few plantations had been done by collecting seedlings from natural forest of Tejpat or from nursery seedlings.

\section{Growth and productivity}

Table 2 : Tree size and leaf production

\begin{tabular}{crr}
\hline $\begin{array}{c}\text { DBH class } \\
(\mathbf{c m})\end{array}$ & $\begin{array}{r}\text { No. of } \\
\text { trees }\end{array}$ & $\begin{array}{r}\text { Average fresh weight } \\
\mathbf{( k g )}\end{array}$ \\
\hline $10-20$ & 2 & 18 \\
$20-30$ & 7 & 40 \\
$30-40$ & 10 & 82 \\
$40-50$ & 16 & 128 \\
$50-60$ & 7 & 190 \\
\hline
\end{tabular}

The harvesting of Tejpat leaf and bark was dependent on the age and growth pattern of the trees. Although the range of the tree age was from one year seedling to 25-year old, the harvesting of leaves began at five years age. The average productivity per tree could be classified into three categories: $100 \mathrm{~kg}$ for $5-10$ years old tree as low, 100-200 kg for 10-15 years as medium, and more than $200 \mathrm{~kg}$ for 15 years and older trees as good (kilogram was estimated from Bhari, 1 Bhari $=$ approximately $35 \mathrm{~kg}$ of fresh leaf). The trees grouped into different DBH classes depicted that most of them were of $40 \mathrm{~cm}-50 \mathrm{~cm}$ DBH (Table 2). The average fresh weight of leaves per tree for different DBH classes ranged from 18 $\mathrm{kg}$ to $190 \mathrm{~kg}$. The trees grown by the farmers revealed moderate negative skewness and a mean DBH of $39.58 \mathrm{~cm}$ (Figure 1).

\section{Biomass estimation}

Correlation coefficients were calculated to find the degree of association between different variables. There were highly significant positive correlations between DBH, height and fresh weight of leaf (Table 3) and also high positive correlation between the height and fresh weight of leaves. The correlation was good enough to estimate the leaf biomass.

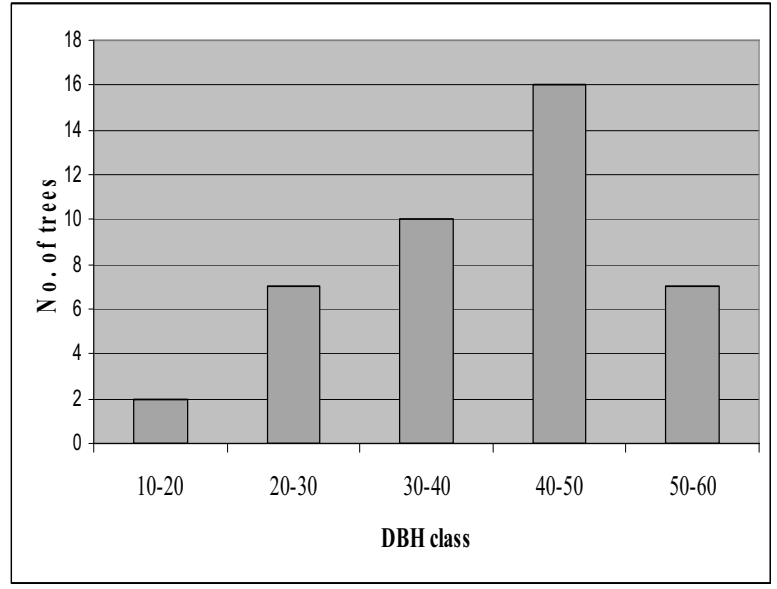

Fig. 1 : Frequency of trees according to $\mathrm{DBH}$

Table 3: Correlation between different variables

\begin{tabular}{lccc}
\hline \multicolumn{1}{c}{ Variable } & DBH (cm) & $\begin{array}{c}\text { Height } \\
\text { (m) }\end{array}$ & $\begin{array}{c}\text { Fresh } \\
\text { weight of } \\
\text { leaf }(\mathbf{k g})\end{array}$ \\
\hline DBH $(\mathrm{cm})$ & 1.0000 & & \\
Height $(\mathrm{m})$ & 0.9123 & 1.0000 & \\
$\begin{array}{l}\text { Fresh weight of } \\
\text { leaf }(\mathrm{kg})\end{array}$ & 0.9021 & 0.8955 & 1.0000 \\
\hline
\end{tabular}

A linear regression line was fitted for fresh weight of leaves and DBH class. The regression coefficient of explanatory variable (i.e. DBH) was statistically significant $(t=13.22, P>|t|=0.000$ at $5 \%$ level of significance, Table 4). The F-test indicated the variances between the two variables were significantly different.

Fitting a simple linear regression line by ordinary least square method (Figure 3), the estimated regression equation was:

$\mathrm{Y}=\mathrm{a}+\mathrm{b}$ DBH or Fresh weight $(\mathrm{Y})=-92.98+5.14$ $\mathrm{DBH}$, where: $\mathrm{a}=$ constant $\mathrm{b}=$ regression coefficient

The plotted data indicated that the deviation of the fresh weight values from the estimated line was higher for high DBH values of trees.

Table 4 : Fitting of regression for DBH and fresh weight of leaf

\begin{tabular}{lrrrrl}
\hline Fresh weight & Coefficient & Std. Err. & t-value & $\mathbf{P}>|\mathbf{t}|$ & $\begin{array}{c}\mathbf{5 \%} \text { significance level, two tailed } \\
\text { test }\end{array}$ \\
\hline DBH & 5.14 & 0.38 & 13.22 & 0.000 & $\mathrm{~F}(1,40)=174.75$, \\
Constant & -92.98 & 15.86 & -5.86 & 0.000 & Prob. $>\mathrm{F}=0.000, \mathrm{R}^{2}=0.81$ \\
\hline
\end{tabular}




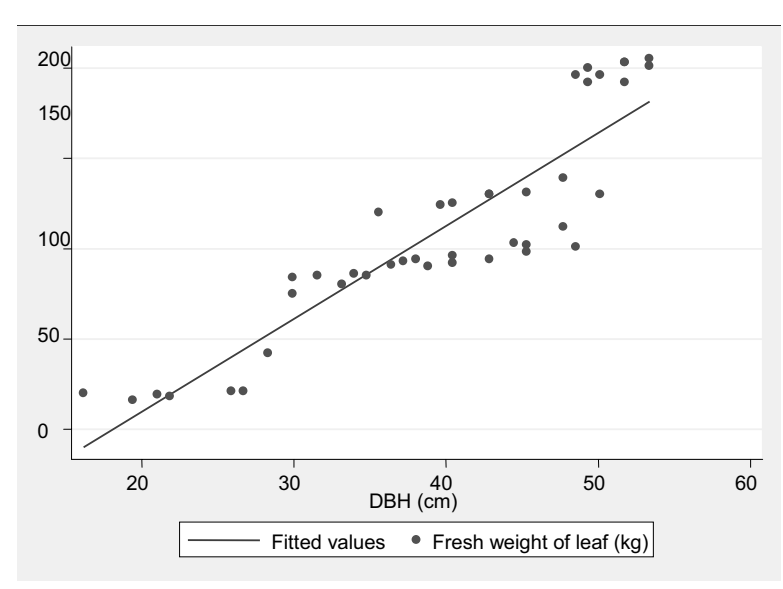

Fig. 2 : Linear regression between $\mathrm{DBH}$ and fresh weight of leaf

\section{Harvesting and use}

Both leaves and bark, called Dalchini, were harvested once a year. The collection period of leaves was from Ashoj (October) to Magh (February) for all farmers. However, the time of bark collection varied from Kartik-Poush (December-January), Baisakh-Jestha (May/June) according to the respondents. The reason for choosing May to June for bark collection was for assessing the sprouting of new leaves on lopped trees and to decide whether or not to debark if any leaves had sprouted up. Further, they revealed that the bark was collected from old, dying, diseased, and thinned trees and the trees producing few leaves. Factors such as age, DBH, and height of tree and leaf collection time were considered for leaf harvesting. Age and maturity were important considerations for bark collection. In most cases, handpicking was preferred for leaf collection because the tools could injure the trees. However, Khukuri was used for older branches. The entire foliage were harvested at one go. Karda (= knife) was a very common tool for debarking the tree from top to bottom as it was easy to debark from the top. Sometimes trees were felled and debarked. Leaf and bark were chiefly used as spice, cuisine flavor, fodder/ bedding for cattle, and for medicines. The small branches and debarked wood were used for fuelwood. Handpicking $\rightarrow$ drying $\rightarrow$ sale was the sequence. The products were purchased by local traders.

\section{Existing problems and needs}

Lack of scientific knowledge on cultivation and harvesting of Tejpat was the overriding problem. There were no training opportunities for the farmers. Other common problems included: leaf and bark diseases, storage problem of harvested products, no regular or systematic markets, dependency and monopoly of traders, and no availability of market in the vicinity. Other bottlenecks were low price, no processing, treatment and transport facilities, and cost ineffectiveness. Warm, dry room with limited ventilation and jute sack were needed for storage. Identification of suitable land for Tejpat cultivation was a serious anxiety for farmers.

The need for training to the farmers on Tejpat cultivation is urgent. There is a need for training to the farmers on treatment of disease, high productivity, information on processing, market structure, etc. Similarly, observation tours, trainings and other extension activities are equally important for introducing scientific management systems. Provision of modern harvesting tools, market facility in the vicinity, seed, fertilizer and treatments, and proper product pricing system with no monopoly could be some measures to tackle the problems. Market control for optimum pricing could be manipulated by the government. Effective initiatives from the government and concerned agencies are required for the promotion of Tejpat cultivation.

\section{Conclusion}

The study on harvesting methods of Tejpat leaf in private land of eastern Nepal has come to the following conclusions:

1. Almost all farmers who had private lands had planted Tejpat trees.

2. The complete lopping of leaves was once a year; bark collection only from old, dying, diseased and low leaf producing trees. The collection period for leaves was from October to February but for bark, it varied from December to January and May / June.

3. The average number of trees per household ranged from 10 to 155 . The mean diameter at breast height $(\mathrm{DBH})$ of the trees was $39.58 \mathrm{~cm}$. The minimum age and size of trees for leaf harvesting were found to be five years and 16.18 $\mathrm{cm}$ respectively. The average fresh weight of leaves per tree for different DBH classes ranged from $18 \mathrm{~kg}$ to $190 \mathrm{~kg}$.

4. There was positive correlation between the DBH and fresh weight of leaf. Fitting of linear regression between fresh weight of leaf and $\mathrm{DBH}$ showed that the estimate was statistically significant at $5 \%$ level of significance. 
5. Some technical and financial supports are needed in that area to enhance the capacity of the farmers and local communities for Tejpat cultivation. There is a need for training to the farmers on treatment of disease, scientific harvesting/ processing, high productivity, market structure.

\section{References}

Amatya, S.M. and Shrestha, K.R. 2003. Nepal Forestry Handbook. Nepal Foresters' Association, Kathmandu.

TISC 2003. Biomass Table of Tejpat. Tree Improvement and Silviculture Component (TISC), Department of Forest, Kathmandu.

Bhattarai, D.R. 2001. Jadibuti Manjari. Mana, Kathmandu.

Edwards, D. M. 1996. Non-Timber Forest Product from Nepal: Aspects of the trade in Medicinal and Aromatic Plants. FORESC monograph 1/ 96, Forest Research and Survey Center, Nepal
Jackson, J.K. 1994. Manual of Afforestation in Nepal. $2^{\text {nd }}$ edition. Forest Research and Survey Centre, Kathmandu.

Khatri, D.B. 1994. Nepal country report. In: Nonwood Forest Products in Asia. (eds.), P.B. Durst, W. Ulrich \& M. Kashio, FAO Regional Office for Asia and the Pacific, Bangkok.

Krishnamurthy, T. 1996. Minor Forest Products of India. Oxford and IBH Publishing Co. Pvt. Ltd., New Delhi

Parajuli, D.P. (1997). Cultivation of Cinnamomum tamala on marginal lands for greater income at Palpa District. Banko Janakari 8(1): 24-32.

Upadhaya, S.P., Kirihata, M. and Ichimoto, I. 1994. Cinnamon Leaf Oil from Cinnamomum tamala Grown in Nepal. Journal of the Japanese Society for Food Science and Technology 41(7): 512-514 